\title{
The Biggest Auction Ever: the Sale of the British 3G Telecom Licences
}

forthcoming, Economic Journal, 2002

the latest version of this paper, and related material, will be at

http://www.paulklemperer.org

Ken Binmore

Department of Economics, University College London

Gower Street, London WC1E 6BT

England

and

Paul Klemperer

Nuffield College, Oxford University

Oxford OX1 1NF

England

Int Tel: +441865278588

Int Fax: +44 1865278557

email: paul.klemperer@economics.ox.ac.uk

First draft: February 2001

This draft: September 2001

\begin{abstract}
This paper reviews the part played by economists in organizing the British third-generation mobile-phone licence auction that concluded on 27 April 2000. It raised $£ 22 \frac{1}{2}$ billion ( $\$ 34$ billion or $2 \frac{1}{2} \%$ of GNP) and was widely described at the time as the biggest auction ever.

We discuss the merits of auctions versus "beauty contests", the aims of the auction, the problems we faced, the auction designs we considered, and the mistakes that were made.

$$
\text { JEL Nos: D44 (auctions), L96 (telecommunications). }
$$

Keywords: Auctions, Telecommunications, Spectrum Auctions, Mobile Phones, 3G, UMTS, Bidding.

* Disclaimer: We led the academic team advising the U.K. government's Radiocommunications Agency, which designed and ran the U.K. mobile-phone licence auction. The views expressed in this paper are ours alone.

Many colleagues, especially Tilman Börgers, Jeremy Bulow, Tim Harford, Margaret Meyer, Marco Pagnozzi, Carol Propper, Mark Williams, and two anonymous referees made very helpful comments. Ken Binmore gratefully acknowledges the support of the Leverhulme Foundation and the Economic and Social Research Council through the Centre for Economic Learning and Social Evolution.
\end{abstract}




\section{NON-TECHNICAL SUMMARY}

Twenty-two and a half billion pounds is a great deal of money to raise for selling air, but that is what the British government raised in an auction for five telecom licences. The auction finished on 27th April 2000, and was frequently described as the "biggest ever". We led the team that advised on the design of the British auction - sometimes called the "3G auction", and this paper summarises our experience.

\section{Auctions are better than beauty contests}

Auctions have many advantages over the alternative, the "beauty contest", in which a government committee awards licences to the firms whose business plans are considered the best.

First, a well-designed auction squeezes information out of the bidders which would never otherwise be available to the government, so is the best way to allocate licences to the firms which are able to use them most valuably. Second, an auction is a transparently fair process, so minimises the political and legal controversy which can arise from beauty contests, where there will always be a suspicion of favouritism. Third, an auction raises money into the bargain which can be used to increase government spending, or to reduce taxes (most taxes cause distortions in the economy, but auctions for licences do not).

\section{Auctions do not harm consumers, nor penalise incumbents}

There are a number of common objections to auctions. One is that they are unfair on incumbent firms, because they are committed to the market and are forced to bid. A second argument is that the high licence fees will mean that firms have little money left to invest in the new technology. A third is that consumers will suffer because prices will be higher to cover the high costs of licences.

All of these arguments are based on misperceptions. For example, it was the high bidding by new entrants which drove prices so high, which shows that firms not committed to the market were still willing to pay. And it is implausible that telecoms firms will either forgo profitable investments or charge less than the market will bear, regardless of whether licences were cheap or expensive.

\section{Encouraging entry is important}

We felt strongly that questions of market structure were much more important than 
the issue of information, on which orthodox auction theory concentrates.

The most important issue of all was to encourage new players to bid in the auction. There was a serious risk that only the incumbents would bother to submit bids, because a potential entrant would not suffer the expense of preparing bids if it had little chance of winning. Our initial design was a two-stage auction, called an "Anglo-Dutch" auction, specifically designed to promote entry.

\section{Different situations need different auctions}

We were able to replace the Anglo-Dutch design with a simpler auction when it became clear that sufficient licences would be available to tempt entrants. Auction design is a case of "horses for courses"; we altered our plans when circumstances changed. Later, the Dutch government faced the scenario which we had feared (selling four licences to four incumbents) but instead of using a design to promote entry, they used an open ascending auction. This design worked well in the UK and badly in the Netherlands - a result which we predicted in advance.

The open ascending auction which worked well in the UK case is a little like those used in Sotheby's or Christies, but instead of one auction there were five going on at the same time. If a company was neither winning nor bidding in one of the auctions it would have to withdraw. This design allowed companies to be flexible about which licence was a target, and also meant that intense competition for the licence we had reserved for entrants would spill over, and mean higher prices for the other licences too.

The small print is important, too

Getting the small print right turned out to be just as important as some of the big design questions. We devoted a lot of time and effort - rightly, in our opinion - to ensuring that there were no loopholes.

Other issues we had to grapple with included whether to use royalty payments, how to determine the number of licences, how to ensure a new entrant would be guaranteed "roaming" on an incumbent's $2 \mathrm{G}$ network, and how to handle "associated" bidders whose ownership is shared.

\section{Experiments help}

Experimental testing in the laboratory and in computer simulations was very helpful. It helped us test our theories, but did much more than that. Experiments are much more 
persuasive than showing them equations, so experimental work helped get our advice accepted. The simulations were also very useful in helping us evaluate a difficult situation - Vodafone's hostile bid for Mannesmann, which would mean that two of the key bidders in the auction had the same owner at the time the auction took place. The experimental work reassured us that this would not seriously damage the efficiency of the auction.

\section{The outcome}

The UK auction ran very smoothly, there was enthusiastic entry and - famously bidding ran high.

Many of the subsequent European auctions did not run so smoothly. In the Netherlands an "off-the-shelf" design, with little thought given to promoting entry, resulted in little competition and low prices. Similar results afflicted Italy and Switzerland. Meanwhile a loophole in the rules of the Turkish auction was successfully exploited to secure a monopoly position, and an auction which was vulnerable to collusion yielded a very poor outcome in Austria.

These auctions also confirmed our views that industrial structure is a critical issue in auction design, and that the worst mistake in running an auction is just to take an auction design off the shelf. Auctions need to be tailored to fit the situation, and economists can prevent some very costly mistakes. 


\section{The Biggest Auction Ever: the Sale of the British 3G Telecom Licences}

Twenty-two and a half billion pounds (34 billion dollars) is a great deal of money to raise for selling air, but that is what the British government raised in an auction for five telecom licences. ${ }^{1}$ The auction ran from 6th March to 27th April 2000, and was frequently described as the "biggest ever" — not since the Praetorian Guard knocked down the entire Roman Empire to Didius Julianus in AD 195 had there been an auction quite as large. ${ }^{2}$

We led the team that advised on the design of the British auction (the "thirdgeneration mobile spectrum licence auction", or "3G auction", or "UMTS auction"). ${ }^{3}$ This paper summarizes our experience. ${ }^{4}$

\section{Background}

In 1997, when our advice was first sought, four mobile-phone companies operated in Britain using "second-generation" (2G) technology. The incumbents were Cellnet, One-2One, Orange, and Vodafone. (British Telecom (BT), the erstwhile state-owned monopolist privatized under Mrs. Thatcher, held a $60 \%$ stake in Cellnet which it increased to $100 \%$ in 1999.) The proportion of the population using a portable phone was rising rapidly ${ }^{5}$ and, as in other parts of the world, the cellular telephone industry was regarded as a runaway success; the industry was set to become even more important with the introduction of the "third generation" of portable telephones that would allow high-speed data access to the internet.

\footnotetext{
${ }^{1}$ The exact total raised was $£ 22,477.4$ million (or about $£ 22,477.3$ million after deducting the cost of the economic consultants - primarily on programming simulations, running experiments etc.).

${ }^{2}$ See Gibbon (1776). The German telecom auction subsequently raised even more in cash terms (although less per head of population) and takeover battles often reduce to a kind of auction with even higher prices

${ }^{3}$ The ESRC Centre for Economic Learning and Social Evolution (ELSE) successfully tendered to the UK Radiocommuncations Agency for the contract. The other economists on the team were Tilman Börgers, Jeremy Bulow, Philippe Jehiel, and Joe Swierzbinski. The laboratory work was conducted by Geoff Miller, Chris Tomlinson, and John McCarthy.

${ }^{4}$ Readers seeking more detail should consult the British Radiocommunications Agency website (www.spectrumauctions.gov.uk). Another useful source is the independent report of the National Audit Office (2001) on the auction, available at www.nao.gov.uk. (The NAO is "totally independent of Government' but 'report(s) to Parliament on the economy, efficiency, and effectiveness [of Government] departments and other bodies'- see the NAO website.)

${ }^{5}$ The number of cellular mobile phones subscribers grew from 1 million to 10 million between 1992 and 1998 , and leapt to 35 million - $60 \%$ of the population - by 2000 , according to Oftel.
} 
How "third-generation" technology will work, and what the final products of the industry will be, remains uncertain even today. In 1997, three years before the auction, predictions were even more fluid. This was of major importance in planning for the auction, because the engineering and the commercial advice received towards the end of the planning period was very different from the advice received at the beginning of the period. It was therefore necessary to keep urging the importance of retailoring the auction design to fit the changing circumstances since, as we shall see, "one size fits all" is a very bad principle in auction design.

Economists had been advocating auctioning radiospectrum at least since Ronald Coase (1959). William Vickrey, in particular, had been pushing the use of auctions in such contexts for many years, but had been left to sing unheard for most of his career. However, the U.S. Federal Communications Commission (FCC) eventually turned to auctioning radiospectrum for phone licences in 1994. The FCC used the "simultaneous ascending auction" design that had first been sketched by Vickrey (1976) and whose details were independently developed by McAfee, Milgrom and Wilson. This auction is much like a standard "ascending" auction used to sell a painting in Sotheby's or Christies, ${ }^{6}$ except that several objects are sold at the same time, with the price rising on each of them independently, and none of the objects is finally sold until no-one wishes to bid again on any of the objects. ${ }^{7}$ The FCC auctions worked fairly well in practice (McAfee and MacMillan, 1996; Milgrom, forthcoming; Klemperer, 1998, 2000a, 2002b), and the fact that $\$ 20$ billion was raised in the initial series of auctions - twice the original estimateattracted much favourable media attention.

The U.K. embraced auctions later than the U.S., and the U.K.'s current "secondgeneration" mobile-phone licences were awarded using a "beauty contest", in which firms submitted business plans to a government committee which awarded the licences to those candidates it judged best met a set of published criteria. But by the late 1990s, economists' arguments for the use of auctions were beginning to make headway in Britain.

\section{Auctions vs Beauty Contests}

8

\footnotetext{
${ }^{6}$ In an ascending auction, the price starts low and competing bidders raise the price until no-one is prepared to bid any higher, at which point the final bidder then wins the prize at the final price he bid.

${ }^{7}$ The design allows a bidder to switch his interest between objects as relative price levels change.

${ }^{8}$ This section is based on Klemperer (2000d).
} 


\subsection{Arguments for Auctions}

Most importantly, a well-designed auction is the method most likely to allocate resources to those who can use them most valuably. ${ }^{9}$ Rather than relying on government bureaucrats to assess the merits of competing firms' business plans, an auction forces businessmen to put their "money where their mouths are" when they make their bids. An auction can therefore extract and use information otherwise unavailable to the government. ${ }^{10}$

Secondly, the difficulty of specifying and evaluating criteria for a beauty contest ${ }^{11}$ makes this a time-consuming and opaque process that leads to political and legal controversy, and the perception, if not the reality, of favouritism and corruption ${ }^{12}$ Indeed, some $^{2}$ governments make no secret of choosing beauty contests precisely because of the possibilities for favouring their "national champions" over foreign firms. But such protectionism is unlikely to benefit consumers or taxpayers.

Thirdly, of course, an auction can raise staggering sums of money to support the public finances - the U.K. auction yielded about $2 \frac{1}{2} \%$ of GNP, or enough money to build 400 new hospitals. A beauty contest, by contrast, can give away valuable assets at a fraction of what they are worth. The winners of the U.K.'s previous "second-generation" licences made original payments in the region of just $£ 40,000 .^{13}$ Economists argued that those

\footnotetext{
${ }^{9}$ Allowing resale is not a perfect substitute for an efficient initial allocation, because resale is itself generally inefficient (Cai, 1997; Myerson and Satterthwaite, 1983; Cramton, Gibbons, and Klemperer, 1987). Milgrom (forthcoming, 2000) ar gues that the resale of phone licences has indeed been inefficient in the U.S. where it has been permitted.

${ }^{10}$ For example, we were advised during the auction development that one of the three smaller licences sold was worth a little less than the other two. But the auction demonstrated otherwise. We have seen exactly the same - firms ranking licences differently from government expectations - in other countries.

${ }^{11}$ Nicholas Negroponte (the technology guru who is one of the most prominent advocates of beauty contests), for example, argues that $3 \mathrm{G}$ licences should be allocated to those who would guarantee the lowest prices to consumers, invest the most in infrastructure, stimulate most creativity, etc. But how can firms guarantee consumer prices for 5-20 years in the future for products that we may not yet even be able to imagine? Infrastructure investment can be costed, but will it all be useful? How can the government possibly decide who will be most creative? And how could the government monitor and enforce any commitments made by firms? How should the government penalize a firm that turns out to be insufficiently creative?, and what should the government's response be to a firm that is creative and develops a product with valuable unforeseen features but above the previously guaranteed price? It is hard to think of a more serious drag on innovation than pre-specifying future prices for products that don't yet exist!

Note that we are not arguing that the government should not specify quality criteria for the licenses, merely that these should be clearly thought out in advance (as, for example, was the UK government's requirement that $3 \mathrm{G}$ licensees roll out a network covering $80 \%$ of the UK population by 2007 ).

${ }^{12}$ The Spanish and Swedish 3G beauty contests, for example, provoked litigation and substantial and still-continuing political debate. By contrast, several losing bidders complimented the U.K. on its auction process.

${ }^{13}$ The operators also pay annual licence fees which had risen to $£ 300,000$ per $\mathrm{MHz}$ by $2000-01$, or about
} 
who advocated beauty contests should say how they would prefer to fund the government. Did they want higher income taxes? ${ }^{14}$

\subsection{Popular Objections to Auctions}

There are several common objections to auctions. They are said to be unfair to firms, to raise consumer prices, and to reduce investment. But all of these complaints are based on misperceptions.

First consider the argument that auctions are unfair to firms who are "forced to bid". It is true that incumbent mobile-phone operators might feel forced to win a new licence, or see the value of their previous investments sharply reduced. But in no European 3G auction have there been fewer licences than incumbents, and the prices of licences were set by the marginal bidders who were therefore new entrants who had nothing to lose if they failed to win a licence. And in the U.K., Germany, Italy and elsewhere, some licences were won by companies who had no previous presence in those markets, further proving that companies who were under no pressure to compete saw the risks as worth taking..$^{15}$ Of course, the companies are taking huge risks in bidding in an auction, just as, for example, firms take huge risks when they invest in developing a new aircraft, a new drug, or a Channel Tunnel. They know that they are buying into a lottery that might result in huge losses or huge gains. Although 3G's prospects look a lot less rosy a year after the auction, and many people now believe that the winners of the British 3G auction "paid too much", only time will tell whether their gamble was a good one. ${ }^{16}$

\section{Price Effects}

The most common fear about auctions seems to be that firms' costs in an auction will be passed on to consumers in the form of higher prices. This would be at least partly true for an auction in which firms bid royalties (see Section 4.2). But the argument is generally

$1 \%$ of the annual rental value of the spectrum implied by the UK third-generation auction prices.

${ }^{14}$ Martin Feldstein (1999) recently estimated that every extra $\$ 1$ of income tax raised in the U.S. costs the economy an additional $\$ 2$ in deadweight losses caused through the disincentives to earn, and the misallocation of resources to avoid taxes. True, Feldstein's estimates may be overstated - 33 cents in deadweight loss would be a more typical estimate (see, e.g., Ballard et al, 1985) — but char ging companies for spectrum incurs none of these additional costs.

${ }^{15}$ Indeed in the U.K. case one winner quickly re-sold shares of its licence to two other new entrants at a profit!. See Section 7.1 .

${ }^{16}$ It is because entrepreneurs take such risks that caution must be exercised in taxing away their profits when things turn out well. 
mistaken in an auction in which firms make once-and-for-all lump sum payments. Like any other firms, telecom companies will charge the prices that maximise their profits, independently of what the spectrum cost them in the past.

One way to explain how sunk costs work to non-economists is to imagine we are now in 2010 and the new cellular telephone services are being sold at whatever prices it turns out maximise their profits. If the government were suddenly to refund the licence fees (with interest, so that it was as though the licences had initially been given away), how would these prices change? Other things being equal, the prices would remain exactly the same, because a company would be irrational to lower its price below what the market will bear; the only result of the refund would be to increase the profit of the shareholders of the operating companies.

To take a more familiar example, consider housing prices. The price of new housing is no lower when the developer had the good fortune to obtain the land below its current market value (e.g. because it was obtained free through inheritance or was bought before planning permission was available) than when the developer has paid the full market value. In either case, the price is determined by the housing market at the time the new housing is sold. There is no more sense in handing out free spectrum to the telecom companies than in failing to charge developers for land in the belief that this will lead to cheaper houses.

Of course, telecom companies (and land developers) have enormous incentives to argue the opposite, because they obtain large windfall profits if they can obtain a scarce resource for free. And it is true that consumer prices can be affected (even by past lump sum payments). For example, paying auction fees could potentially create "focal points" that allow firms to tacitly co-ordinate on charging higher prices. Paying auction fees also makes firms poorer, so perhaps more willing to risk collusion, especially if they believe they are too poor to afford any fines. And an auction will, in principle, select those firms that are better able to collude (hence are more profitable). But all these effects seem small, and certainly avoidable with good competition policy.

Much more worrying is that companies' specious arguments may fool politicians and regulators into agreeing that the auction is a reason for allowing artificially high prices. ${ }^{17}$ If we do see higher prices in countries that ran auctions, it will probably be because of these political effects.

\footnotetext{
${ }^{17}$ There are some signs that this might happen in the U.K. and Germany. For example, Oftel (the U.K.'s telecoms regulator) will be doing just this if it accepts operators' arguments that it should permit firms to set higher call-termination fees to "reflect" firms' sunk auction costs.
} 


\section{Investment Effects}

A final concern is that large auction fees may slow investment because of capitalmarket constraints. Of course this is theoretically possible, ${ }^{18}$ but it seems unlikely that very many highly profitable investments are being foregone because of difficulty raising funding for them. ${ }^{19}$ Giving licences away to firms at discounted prices would certainly relax firms' capital-market constraints, just as any other state handouts would. There may perhaps be good grounds for subsidising this industry, but advocates of giveaways need to explain quite a lot: Why subsidise this industry rather than others? Why subsidise the mobile-phone operators (rather than, for example, providers of content to be transmitted over the mobile-phone networks)? Why subsidise them to this extent?

Furthermore, even a government that accepted (as the British government did not) that auctions would slow investment (or raise prices to consumers) might find it in its own national interest to run an auction, because the auction revenues accrue only to the country itself while any investment effects apply to other countries too- the fact that Telefonica's consortium spent over $\$ 7$ billion on a licence in Germany and almost nothing on its Spanish licence is obviously not an argument for Telefonica to invest less in Germany than in Spain. ${ }^{20}$ (In fact some commentators have suggested the opposite, arguing that internal-organisational incentives will drive firms to launch their services faster in Germany to demonstrate that they can quickly recoup their auction costs. ${ }^{21}$ )

\section{attn Printer: leave small gap here}

Occasionally - for example, when there are too few potential bidders, or large costs of supplying necessary information to bidders - a form of structured negotiations may be

\footnotetext{
${ }^{18}$ For example, the "pecking order" theory of funding suggests that depleting a firm's cash by upfront payments raises the firm's cost of capital, and the finance literature is replete with examples where capital structure matters for firm efficiency, see, e.g. Wruck (1994).

${ }^{19}$ In fact, by summer 2001, at least four of the five winners of the U.K. 3G licences, including the new entrant, had arranged the necessary funding for their new U.K. networks.

${ }^{20}$ The Spanish government may have noticed this. It is belatedly trying to levy large fees on the winners of its beauty contest.

${ }^{21}$ Indeed two of the winners of the U.K. licences have said that the high price they paid for the licences in the auction encouraged them to develop 3G services faster than if the spectrum had been given away.
} 
better. $^{22}$ However the general rule is that auctions treat firms fairly and transparently, and yield the greatest possible benefits for consumers and taxpayers.

In the autumn of 1997 therefore, the U.K. government asked us to help design a 3G auction.

\section{Aims of the Auction}

Unlike some governments, the British were honest in pursuing their published aims. An originally fuzzy set of aspirations, reflecting various different interests and constrained by European Commission directives, were gradually refined into the following set of objectives:

- To assign the spectrum efficiently;

- To promote competition;

- To "realise the full economic value" (subject to the other objectives). ${ }^{23}$

In the event, the competition aim was addressed by permitting no bidder to hold more than one licence, and auctioning the maximum number of licences given the available spectrum and the need to make them large enough for viable businesses.

As for the other objectives, our clear instructions were that efficiency considerations were to take priority over revenue considerations.

Efficiency was understood as putting the licences into the hands of the bidders with the best business plans. Since a bidder with a better business plan will generally value a licence more ${ }^{24}$ this aim roughly reduces to seeking to maximise the sum of the valuations of the bidders who are awarded licences. ${ }^{25}$

\footnotetext{
${ }^{22}$ See Bulow and Klemperer (1996).

${ }^{23}$ In a written answer to a Parliamentary Question, Barbara Roche, then Minister for Small Firms, Trade and Industry, said "In offering through an auction licences to use specified frequencies for the delivery of UMTS, the Government's overall aim is to secure, for the long term benefit of UK consumers and the national economy, the timely and economically advantageous development and sustained provision of UMTS services in the UK. Subject to this overall aim the Government's objectives are to (i) utilise the available UMTS spectrum with optimum efficiency; (ii) promote effective and sustainable competition for the provision of UMTS services; and (iii) subject to the above objectives, design an auction which is best judged to realise the full economic value to consumers, industry and the taxpayer of the spectrum." See Hansard, 18 May 1998.

${ }^{24}$ Of course, there are reasons why this need not be true.

${ }^{25}$ Note that the government was unwilling to permit resale (see Section 4.1), but resale cannot in any case be guaranteed to achieve efficiency (see note 9). Note also that while some commentators have argued that more spectrum should have been sold off, that possibility was beyond our control: the amount of spectrum to be used for 3G licences had been pre-determined by international treaty.
} 
But how does one find out the bidders' valuations? There is no point in simply asking the bidders. If asked, each bidder will earnestly insist that his value is the highest. An auction gets around this problem by making bidders back their plans with their money. So promoting efficiency necessarily involves raising revenue which, happily, fits with the government's last objective of "realising economic value".

In view of the $£ 22.48$ billion that the auction raised, the media expressed profound scepticism about revenue being genuinely last on the list of priorities, but the British government could obviously have made substantially more money by selling fewer licences. ${ }^{26}$ How much money it would have made by creating a monopoly by selling just one licence beggars the imagination!

\section{Main Issues}

Our first task was to assess the economic and legal environment in which the auction would take place, and offer a menu of auction designs from which the Radiocommuncations Agency could make an initial choice.

\subsection{The Problem of Entry}

We felt strongly that questions of market structure were substantially more important than the informational issues on which orthodox auction theory focuses. ${ }^{27}$ Events were to show that we were even more right in this judgement than we knew.

The essential structural problem in auctioning $3 \mathrm{G}$ telecom licences is that the incumbents who are already operating in the $2 \mathrm{G}$ telecom industry enjoy a major advantage over potential new entrants, so it may be hard to persuade potential entrants to bid. Not only are the incumbents' $2 \mathrm{G}$ businesses complementary to $3 \mathrm{G}$, but their costs of rolling out the infrastructure (radio masts and the like) necessary to operate a $3 \mathrm{G}$ industry are very substantially less than those of a new entrant, because they can piggyback on their $2 \mathrm{G}$ infrastructure. ${ }^{28}$ Incumbents also have the advantage of established customer bases and brand-name recognition. These considerations loomed even larger in the early planning

\footnotetext{
${ }^{26}$ Not only would reducing the number of licences reduce competition in $3 \mathrm{G}$ services and so increase the total profits in the industry, but reducing below four licences would exclude an incumbent operator.

${ }^{27}$ Jehiel and Moldovanu's (1996) and Jehiel, Moldovanu and Stacchetti's (1996) work on "externalities" was a notable exception, as is Jehiel and Moldovanu's (2001) recent model concerning market structure considerations inspired by the 3G auctions. See Klemperer $(1999,2000 \mathrm{~b})$ for summaries of the extensive auctions literature.

${ }^{28}$ Furthermore, there is the possibility that the regulations might in some circumstances be altered so that the spectrum licensed for 2G purposes can be "refarmed" for 3G purposes (though the Government made clear that no commitments could be made on how and when refarming would be implemented).
} 
stages, because market research indicated that the more obvious potential entrants were not yet showing any great interest in the coming British 3G industry, and so there were no good reasons for being optimistic about entry to the auction.

Our initial report therefore emphasized the importance of encouraging entry to the auction in pursuit of the aim of promoting competition. Two of the measures we suggested, allowing resale and making bidding credits available to the entrants, were ruled out for various reasons. But we were successful in advocating that the government mandate "roaming", which would allow an entrant access to the incumbents' $2 \mathrm{G}$ network at a regulated price. ${ }^{29}$

\subsection{Royalties or Lump Sum Payments?}

Payment for licences using a royalty rather than a lump-sum fee is another way of promoting entry, both because it allows the government to share the risk with an operator, and because new entrants are likely to make smaller payments for any given royalty rate, but we were unenthusiastic about using royalties. They must necessarily be levied on some genuinely observable variable, which profit is not. So they are usually based on some correlate of revenue. For example, in some American oil-tract auctions, the royalty is based on an independent metering of the oil pumped to the well-head, valued at that day's market price.

However, a royalty based on revenue corresponds to a "value added tax" and so creates deadweight losses in an oligopolistic industry such as telecoms, for exactly the same reason that a sales tax makes a monopoly or oligopoly worse. Moreover, a royalty of the form $x$ cents per phone call corresponds to a specific tax and is even more distortionary. ${ }^{30} \mathrm{By}$ contrast oil has, roughly speaking, a "world price" that is largely unaffected by any one country levying a royalty.

Royalty payments also allow bidders to default, or to attempt renegotiation if optimistic predictions of demand turn out to be mistaken. One therefore faces the risk that a buyer may treat his purchase only as an "option to buy". Many of the U.S. spectrum auctions suffered from this kind of behaviour-winners were not required to make payments upfront and some simply never paid - which caused the FCC administrative difficulty and

\footnotetext{
${ }^{29}$ See Section 6.1. We were of course not alone in our concern to attract entry. Advice from Oftel and N. M. Rothschild and Sons Ltd. was also important.

${ }^{30}$ To see that a proportional tax (or royalty) on revenue is less distortionary than a per-unit (specific) tax, observe that the former corresponds to the sum of (i) a non-distortionary proportional tax on profits (= revenues - costs) plus (ii) a distortionary proportional tax on costs. For a given amount of tax raised, this is less distortionary than a per-unit tax. See Bulow and Klemperer (1998) for further discussion.
} 
political embarrassment.

All these problems arise when royalties are pre-set by the government. If firms bid royalties, the problems are even worse: the US Department of the Interior ran a very unsuccessful experiment with royalty-based auctions for oil-tracts about 20 years ago, in which the government fixed a relatively small up-front "bonus" payment, and the companies bid percentages of their revenues. The result was that many speculators bid enormous royalty rates in order to win licences. If the oil-fields turned out to be highly productive they could make money even at the high royalty rates, but most fields were simply not developed, even when it was economically efficient to do so. (For example, a winner paying an 80 percent royalty would develop a field only if it yielded a return more than five times the production cost.)

And, of course, further distortions would be created in an oligopolistic market like telecoms if different winners paid different royalty rates.

In spite of these problems, we considered schemes in which payment would involve both royalties and a lump-sum fee. However, such schemes were ruled out by various technical and other considerations and given a straight choice between royalties and lump-sum fees it was clearly right to recommend the latter. Although economically efficient, this choice attracted considerable criticism from commentators unable to distinguish between the impact of a sunk cost and a variable cost on pricing decisions (see Section 2). ${ }^{31}$

\subsection{How Many Licences?}

We were also anxious that engineering concerns about the higher quality of service made possible by issuing large licences should be properly balanced by an appreciation of the benefits to consumers of the increased competition made possible by issuing a larger number of smaller licences.

Many officials are attracted by the idea pushed by incumbent firms that the "market" should decide how many licences there should be. But this confuses two different markets; the interests of the consumers who participate in the phone market created by the auction are not represented in the auction "market" for licences. We considered a number of possible designs in which the number and size of the licences would be determined endogenously in the auction, but advised that an efficient allocation of licences across

\footnotetext{
${ }^{31}$ With some honorable exceptions, much of the media seemed very slow in catching on to the significance of the auction, and singularly ill-informed on economic realities when they did. This was disappointing, since although we personally were not allowed to talk to the media about events in the auction while it was going on, the government put extensive effort into media briefing.
} 
bidders could not be guaranteed, and that only unacceptably complex designs would provide reasonable protection against the emergence of an anticompetitive industry. ${ }^{32}$

So in the end the U.K. government chose to auction a fixed number of licences, permitting no bidder to win more than one licence.

\subsection{Legal Issues}

On several occasions we had to get involved with the legal fine print.

We had to argue more than once that bids must be binding. Permitting bidders to withdraw them later would have reduced the bids to cheaptalk and made a mockery of the process.

We also had to insist that any reserve price should be a clear commitment not to sell if the bidding did not meet the price. If bidders expected that the government would immediately turn around and re-auction any unsold licence at a lower price, then the reserve prices would have no meaning. We won this point in the end, but reserve prices actually played little role in the auction because the information available to the government was limited so it was appropriate to set reserves very cautiously. ${ }^{33}$

Awkwardness in the wording of the relevant Telecommunication Act required us to develop special implementations of some of the auction formats we were proposing. While we could always find an implementation of our ideas that circumvented the problems, considerable care was sometimes required. Changing the wording of the Act would have risked delaying the auction and was probably not politically viable.

It would be easy to underestimate the difficulty of ensuring that the small print does not somehow undermine the principles of an auction design.

\section{$5 \quad$ Auction Designs}

\subsection{The Anglo-Dutch Design}

Our preliminary analysis considered the implications of various different numbers of licences being put up for sale. The worst case for the success of an auction was that only

\footnotetext{
${ }^{32}$ We also wanted to avoid any risk of a "sorry winner" who bid rationally to maximise expected profit but ended up losing money because of the particular behaviour of other bidders. (See Pagnozzi, 2002). Such a sorry winner may litigate, or default, and so embarrass the government. For example, the German and Austrian 3G auctions, which determined the number of licences within the auction, ran the risk of creating sorry winners, even though this turned out not to be the biggest problem of these auctions. See Klemperer (2002a, b).

${ }^{33}$ Reserve prices should have played a larger role in the subsequent European 3G auctions (see Section $7.3)$.
} 
four licences would be available- one for each of the four $2 \mathrm{G}$ incumbents. Given that the incumbents would be bidding from an advantaged position, why would a potential new entrant spend any money preparing to bid in an auction?

So when it seemed that engineering considerations made it impossible to provide more than four licences, each of roughly equal size, we felt that our major problem was to promote entry to the auction. The design of the auction could not be expected to have the same sort of effect on entry as matters like the provision of roaming rights, but we nevertheless thought it important to do what could be done.

Where entry is a concern, an ascending-price auction is not ideal. An example of the problem was the sale of the Los Angeles licence in the big American telecom auction run by the FCC. The licence was acquired cheaply by the incumbent, Pacific Bell, which faced little risk in implementing its widely advertised strategy of not being beaten in Los Angeles. All it had to do was to persistently make the minimum overbid if an entrant challenged, until the entrant gave up the hopeless struggle (Klemperer, 1998). Under these circumstances, the FCC were lucky that Pacific Bell faced any challenge at all. ${ }^{34}$ For similar reasons, some recent ascending-price telecoms auctions, notably the Swiss 3G auction, have been fiascos in which there were no more bidders than licences (Klemperer, $2002 \mathrm{a}, \mathrm{b}){ }^{35}$

Sealed-bid auctions do better at promoting entry because they give entrants a better chance of winning against strong incumbents (Klemperer, 2002b). However, sealed-bid auctions do not allow bidders to gather information on the business plans of their rivals by observing who is staying in and who is getting out as the price rises. They therefore make it impossible for bidders to refine their valuations of the licences on the basis of this information. In an attempt to capture the desirable features of both auction types, we proposed what we called an Anglo-Dutch design. ${ }^{36}$

In an Anglo-Dutch auction for one object, the price rises until all but two bidders quit and the last two bidders then make "best and final" sealed bids with the winner paying the price he bid in this final round. So an Anglo-Dutch auction resembles the process by which houses are sometimes sold; the fact that we could describe it in terms of this

\footnotetext{
${ }^{34}$ The activity rules for the auction meant that some bidders placed (low) bids on licences they had no expectations of winning in order to maintain eligibility to win other licences later in the auction.

${ }^{35}$ See also Bulow and Klemperer (2002); Bulow, Huang and Klemperer (1999); Gilbert and Klemperer (2000); and Klemperer and Pagnozzi (2002).

${ }^{36} \mathrm{~A}$ Dutch auction is equivalent to a first-price, sealed-bid auction. An English auction is the prototype of an ascending-price auction. The Anglo-Dutch auction was first proposed and described in Klemperer (1998).
} 
very familiar institution was important for our ability to sell the proposal to government officials, who in turn had to explain the proposal to their political masters.

In our case we had four licences to sell, so the price would rise until only five bidders remained. The surviving bidders would then be committed to bid at or above this price in a sealed-bid auction in which the four highest bidders are awarded a licence.

We considered two versions of the Anglo-Dutch; one in which each winner is committed to paying his own bid, and one in which each winner is committed to paying the fourthhighest winning bid. The prospective bidders preferred the latter design, as did we. ${ }^{37}$

Finally, although the four licences that were to be offered were close substitutes, they were not sufficiently similar that they could be assigned arbitrarily. A third stage, modeled on the standard simultaneous ascending design used by the U.S. FCC, was therefore introduced to determine who got which licence and at what price.

Since the three stages of an Anglo-Dutch auction are quite complicated, we thought it especially important to test its efficiency in the laboratory. The short deadlines with which one is typically faced in consulting work are particularly troublesome in experimental work, since one is left with very little time to sort out the teething problems that always turn up after running a few pilots. In this case, the original pilots seemed to indicate that the design was hopelessly inefficient. However, the amount that subjects are paid for their time and attention can sometimes be critical in laboratory experiments, and so it proved here. Subjects were paid a flat attendance fee and an amount proportional to the profit they made for the company on whose behalf they were told they were bidding. After doubling the latter rate of payment (so that subjects left with an average of $£ 50(\$ 70)$ ), the experimental results became close to efficient. We used two rough-and-ready criteria to judge efficiency in a variety of scenarios about relative valuations that market research rendered plausible. In terms of money, we found that the sum of the valuations of the allocated licences was always within 2 or 3 percent of the theoretical maximum. In terms of an ordering of all possible allocations of the licences, the experimental allocation usually achieved the social optimum, sometimes achieved the second most efficient allocation, and

\footnotetext{
${ }^{37}$ The latter (uniform-price) design is likely to be more efficient given the need for the third, simultaneous-ascending, stage discussed in the next paragraph.

If desired, it can be run without revealing the winners' bids by isolating the five bidders from each other and running an ascending auction, keeping the first quit secret from the other bidders, stopping the auction only when the second quit is announced to the auctioneer, and then selling to the four winners (including the second quitter) at the final price. From the bidders' point of view this procedure is equivalent to a uniform-price sealed-bid auction, that is, the second quit-price in this procedure would equal the fourth-highest sealed-bid price.
} 
was only occasionally worse. ${ }^{38}$

The Radiocommunications Agency therefore bravely decided to go ahead with the proposed Anglo-Dutch design, in spite of fierce criticism from the incumbents, who could not be expected to welcome a design intended to promote entry. ${ }^{39}$ We think that their experience in playing the roles of bidders within our experimental software had a significant effect in bolstering the confidence of noneconomists on the auction team in the workability of the design. (By contrast, mathematical equations have very little persuasive power.)

However, all the work developing and testing the Anglo-Dutch design proved unnecessary when the engineering advice changed and we were informed that it would be possible to make five licences available instead of four.

\subsection{The Simultaneous Ascending Design}

The five licences that we were now advised could be fitted into the available spectrum were of different sizes (because of the need to observe the international UMTS standard for third-generation mobile that required spectrum to be bundled in $5 \mathrm{MHz}$ chunks). Some licences would therefore be valued very differently from others by the bidders in an auction. Licence $A$ is the largest, comprising $2 \times 15 \mathrm{MHz}$ of paired spectrum plus $5 \mathrm{MHz}$ of less-valuable unpaired spectrum. Licence $B$ is a little smaller, comprising $2 \mathrm{x} 15 \mathrm{MHz}$ of paired spectrum, but no unpaired spectrum. Licences C, D and E are all roughly the same, each comprising $2 \mathrm{x} 10 \mathrm{MHz}$ of paired plus $5 \mathrm{MHz}$ of unpaired spectrum, but these three licences were thought substantially less valuable than the other two. ${ }^{40}$

The existence of five licences solved the overall entry problem, especially when it was decided to restrict the incumbents in the $2 \mathrm{G}$ industry to licences $\mathrm{B}, \mathrm{C}, \mathrm{D}$ and $\mathrm{E}$, so ensuring that one of the two large licences would go to a new entrant. (There was concern about whether new entrants would be interested in the smaller licences.) The raison d'etre for the Anglo-Dutch design therefore vanished. Furthermore, it might not have worked as well for licences of very different sizes as it would have worked when the licences were of very similar values.

\footnotetext{
${ }^{38} \mathrm{~A}$ bidder commissioned experiments (Abbink et al, 2001) that found that the Anglo-Dutch design did not necessarily promote more entry than does a uniform price auction, but the setting it tested was one in which (unlike ours) entry is relatively easy in either case.

${ }^{39}$ One major bidder employed two Nobel prizewinners in the hope of finding arguments to oppose the design.

${ }^{40}$ With six licenses, there was thought to be a substantial risk that no license would be large enough to attract an entrant.

Each license was to last until the end of 2021, and included an obligation to roll out a network covering at least $80 \%$ of the UK population by 2007 .
} 
So with five licences and only four incumbents, we advised abandoning the AngloDutch design in favour of a modified version of the simultaneous ascending design pioneered by the FCC. We believed that the design would work even better for us, since the fact that each bidder was restricted to getting at most one licence insulated us against the problems with collusion that arose in America. ${ }^{41}$

Our design entailed multiple rounds of simultaneous bids. In the first round, each bidder makes a bid on one licence of its own choice. To remain in the auction, a bidder must be 'active' in every subsequent round. An active bidder either currently holds the top bid on a particular licence, or else raises the bid on a licence of the bidder's choice by at least the minimum bid increment. ${ }^{42} \mathrm{~A}$ bidder who is inactive in any round is eliminated from the rest of the auction. A bidder who currently holds the top bid on a licence cannot raise or withdraw its bid, nor bid on another licence in the current round. At the end of every round all bidders' bids are revealed, the current top bidder for each licence is determined, ${ }^{43}$ and minimum bid increments are set for the next round. The auction concludes when only five bidders remain. They are each then allocated the licence on which they are the current top bidder at the price they have currently bid for that licence.

This design ensured that even if new entrants had only been interested in the two large licences, the competition for these would have spilt over to the smaller licences too. The incumbents would engage in arbitrage, switching their bids to whichever licence seemed best value to them, so as the prices of the large licences were driven up, the prices of the smaller ones would have had to follow, and the price of every licence would have been determined by real competition.

Apart from its transparency, and from generating competitive prices, the design has two important advantages, which we explain on the assumption that the minimum raise is always negligible. The first is the simplicity of bidders' strategies. Consider the case of "private values", that is, when every bidder is completely confident of the exact value to

\footnotetext{
${ }^{41}$ If the spectrum was divided into many small blocks, with bidders allowed to win multiple blocks, bidders might try to collude to divide the blocks between them; roughly this seems to have happened in some of the U.S. auctions (Engelbrecht-Wiggans and Kahn, 1998; Brusco and Lopomo, 1999; Cramton and Schwartz, 1999, 2000; Klemperer, 2002b). If bidders can win just one licence each, every bidder is either a winner or a loser-there is no middle ground-and collusion is much harder.

${ }^{42}$ A bidder could also remain "active" by using one of three waivers allowed per bidder or, when eight or fewer bidders remained, by calling for one of two recesses allowed per bidder. Each recess would stop all bidding for a day.

${ }^{43}$ In the event of a tie on a licence the "top bidder" for that licence was designated randomly. (The rules allowed the auctioneer to instead ask the tied bidders to each rebid at least as high on the licence in question, and the intention was as far as possible to use whatever tiebreaking rule made the bidders happiest. In the event, the bidders proved to be as unconcerned as we were about this detail.)
} 
himself of each object, and these values are independent of who wins the other objects and at what prices. Assume bidding is costless, and that at every point of time every bidder assigns a positive probability (which may be arbitrarily small) to the possibility that each rival will be willing to make no further bid, so each bid may possibly be the last one. ${ }^{44}$ In each round, a bidder should then simply make the bid that would maximise his profit if that bid were the last. A bidder should therefore never make more than the minimum raise, and always choose the licence with the greatest gap between the minimum required bid and his value for the licence. In the general case, relaxing the assumption of "privatevalues", things are a little harder; in particular, a bidder must adjust his valuations for the licences if the previous bidding of his rivals shakes his confidence in his business case but, having done that, bidding as described previously is still a reasonable strategy to recommend. ${ }^{45}$

A second advantage is that the design generates an efficient outcome when bidders with "private values" who are not budget constrained behave as described above. To see why, note that at the end of the auction the prices are such that every bidder, including every loser, would choose to buy exactly what he ends up with, given the prices. Therefore no reallocation of licences among bidders, given the prices, could raise the surplus of any individual bidder. So since prices are just a transfer between the buyers and the seller, the total surplus of the buyers and the seller cannot be increased by first reallocating the licences in any way and then changing the prices in any way. So even if different prices were used the auction's outcome must maximise the sum of the values of the winning bidders, which is what we understood by "efficiency" (see Section 3 ). ${ }^{46}$

Of course, these advantages need not apply under other assumptions, in particular the case in which a bidder may quit early or fail to enter the auction because bidding is not costless and he believes he has very little chance of winning a licence. So only when a fifth licence was available to attract new entrants did we feel comfortable recommending the simultaneous ascending design.

In early 1999 the decision was made to proceed with the simultaneous ascending design.

\footnotetext{
${ }^{44}$ These assumptions exclude the case in which a bidder quits before reaching his value for a license (or even fails to enter the auction) because he knows he cannot win the license.

${ }^{45}$ The precise conditions under which such bidding behaviour is optimal remain a subject for debate among both theorists and practitioners.

${ }^{46}$ To illustrate the point mathematically, imagine that an auction for only two licences ends with bidder 1 obtaining licence $\mathrm{A}$ for $£ a$ and bidder 2 obtaining licence $\mathrm{B}$ for $£ b$. Using Greek letters for bidders' valuations and assuming the minimum allowable raise is negligible, we have that $\alpha_{1}-a \geq \beta_{1}-b$ and $\beta_{2}-b \geq \alpha_{2}-a$. Adding the two inequalities yields $\alpha_{1}+\beta_{2} \geq \alpha_{2}+\beta_{1}$. The outcome is therefore efficient insofar as the winners are concerned. It is obviously also efficient in respect of losers, because losers' valuations cannot be above $a$ and $b$, and hence must be lower than winners' valuations.
} 


\section{Other Issues}

\subsection{Roaming}

At a late stage, One-2-One and Orange mounted a successful legal challenge against mandated "roaming", throwing our plans into disarray since it was unclear whether any entrants would bid without guaranteed roaming onto an existing $2 \mathrm{G}$ network.

However, new entrants needed only one incumbent network to roam on, and one incumbent was prepared to offer roaming, conditional on itself winning a $3 \mathrm{G}$ licence. So new entrants would be prepared to bid if they were permitted to withdraw any winning bids in the event that this incumbent failed to win, with the government then re-auctioning the corresponding licences in this event.

The difficulty was that this incumbent might then strategically avoid winning, deliberately triggering the withdrawal of the winning entrants so that it could win a cheap licence in the re-auction. We overcame this danger by inserting an extra stage into the game. If this incumbent failed to win a licence, the other $2 \mathrm{G}$ incumbents would then be asked whether they were now, after all, prepared to permit roaming. If any of them were, the auction result would stand. The point is that the other incumbents would likely see this as an unmissable opportunity to exclude a strong competitor from $3 \mathrm{G}$. And the first incumbent would therefore be most unlikely to run the risk of strategically avoiding winning in the original auction.

In the end, two incumbents, BT and Vodafone agreed to offer roaming voluntarily, so this scheme was not needed. ${ }^{47}$

\subsection{Associated Bidders}

The European telecom industry is rather incestuous, with potentially many pairs of "associated bidders" whose ownership is sufficiently shared that both could not be allowed to win licences without damaging the competitiveness of the U.K. 3G market we were creating. For example, Cellnet was jointly owned by BT and Securicor at the time, so not more than one these three firms could be permitted to win. We saw no very satisfactory way of modifying the auction rules to guarantee that only one of any associated pair won a licence. Instead, therefore, we made provision for a pre-auction in which it could be decided which of two or more closely associated bidders should go forward to the main

\footnotetext{
${ }^{47}$ Furthermore, the Court judgement in favour of One-2-One and Orange was subsequently overturned on appeal in favour of the government.
} 
auction. $^{48}$

As we hoped, the pre-auction was not used in practice. We saw the pre-auction as a stopgap measure designed to provide a clear status quo for the bargaining between associated bidders when they sort out their cross-ownership problems themselves. The pre-auction would also have disadvantaged associated bidders relative to the other bidders, so gave them an incentive to sort out their common ownership problem in advance of the auction. In the event, BT bought out Securicor's share of Cellnet in July 1999 and then bid only as BT3G, thereby resolving the most pressing association problem.

We do not believe that actually running pre-auctions of this kind is a good way of solving problems with associated bidders, even though it might make the best of a bad job. So we hope that such pre-auctions will not be seen as a standard preliminary to a telecom auction. When associations begin to be even a little bit complex, there is no guarantee that their outcomes will be efficient.

In our case, the pre-auction fulfilled its function by providing some encouragement for the bidders to work out their problems themselves.

\subsection{The Vodafone-Mannesmann Takeover}

In October 1999, one of Germany's two largest mobile-phone operators, Mannesmann, took over Orange for almost $\$ 35$ billion. This left Vodafone in a quandary, since it had been contemplating an alliance with Mannesmann, but this was no longer possible as Orange was one of its strongest 2G competitors in the U.K. In the event, Vodafone decided to attempt the biggest takeover ever, and the first hostile takeover in modern history of a German company, by making a bid for Mannesmann-Orange. Vodafone simultaneously appealed that both Orange and Vodafone should be allowed to bid in the British 3G auction if the takeover were successful, pending the divestment of Orange after the auction.

This appeal left the British government in a difficult position.

\footnotetext{
${ }^{48}$ The pre-auction would have consisted of every associated bidder bidding in an ascending auction on a price per $\mathrm{MHz}$ basis until it either quit, or all those associated with it had quit. Once all associations had been broken, bidders who had quit would have been considered for re-entry in the reverse order in which they quit; each bidder who had quit would have been re-entered at the price at which it had quit if this was possible without recreating any association. Finally, each survivor would have been required to begin the main auction with a bid at the price per $\mathrm{MHz}$ at which it become unassociated, or at which it rejoined the pre-auction. Of course, these rules are very rough and ready, and we did not expect them to be needed in practice.
} 
The situation was not an ordinary "associated bidders" problem since Vodafone was committed to divesting Orange, so allowing both to win licences caused no competitionpolicy problems, and indeed would very likely be efficient. And (by contrast with BTCellnet-Securicor) the common-ownership problem could not necessarily be quickly resolved, because complex provisions of German law meant that Vodafone could not guarantee divesting Orange until several months after the conclusion of a successful takeover of Mannesmann.

Denying the appeal and proceeding with the 3G auction could seriously interfere with Vodafone's chances of success in its takeover bid. Even if Vodafone did, nevertheless, successfully take over Mannesmann-Orange, denying one or both of Vodafone and Orange the chance to compete in the auction would have seriously damaged the excluded business(es), and most likely have generated an inefficient allocation of licences.

One option was to delay the auction, but this would have risked creating market uncertainty and delaying the introduction of $3 \mathrm{G}$. The auction team was also very keen to maintain the advantage of being the first of the $3 \mathrm{G}$ auctions. We thought subsequent 3G auctions might attract less entry since bidders would work out from the first auction who the likely winners were in future auctions. The later auctions would also be less competitive if bidders formed more alliances. Furthermore prices in the first auction might be driven higher if bidders thought that winning that auction gave them a competitive advantage in future auctions. The decision not to delay proved very wise. There was in fact much less entry and competition in later 3G auctions (Netherlands, Germany, Italy, Austria, Switzerland, Belgium, Greece, Denmark) and much lower prices in most of them (see section 7.3, and Klemperer, 2002a).

In deciding whether to grant the appeal, a major concern for the British government was the extent to which joint ownership of Orange and Vodafone would injure the aim of allocating the licences efficiently, if both were allowed to bid with appropriate "chinese wall" requirements, forbidding the exchange of relevant information and the coordination of bids. The point is that Vodafone, as temporary owner of Orange, would have an interest in maximizing the sum of Vodafone and Orange's profit in the auction, rather than simply maximizing its own profit. Advising on the efficiency implications of this at short notice was the most stressful event in the whole auction design process. However, some simple theoretical calculations and our computer simulations both indicated that, within the range of likely relative valuations of the licences, the effect on efficiency would be negligibly small. 
Since it was a finely balanced decision whether to permit both Orange and Vodafone to bid in the British 3G auction if Vodafone's takeover of Mannesmann were successful, our report may have tipped the scales in favour of both being allowed to bid with appropriate legal safeguards. In the event, Vodafone took over Mannesmann for about $\$ 175$ billion. There is no evidence that this led to any inefficiency in the auction bidding. After the auction, Orange was bought by France Telecom for over $\$ 40$ billion.

\section{Assessment}

\subsection{The Auction Outcome}

Beginning the planning so far in advance of the auction (almost three years in advance as it turned out) proved a shrewd move by the U.K. government. It allowed us plenty of time to develop and test our ideas and, just as importantly, it allowed for a sustained marketing campaign ${ }^{49}$ without Britain being overtaken in the race to be first on the European scene (indeed worldwide) with a $3 \mathrm{G}$ auction.

By 15 February, 2000, interest in acquiring a licence had reached boiling point. Thirteen serious candidates had qualified to bid in the auction, with the media that took notice predicting that licences would sell for a total of about $£ 2-5$ billion (or about $\$ 3$ $7 \frac{1}{2}$ billion). The first round of the auction took place on 6 March, 2000, when a little more than the sum of the reserve prices, $£ 500$ million ( $\$ 750$ million), was bid. The first withdrawal came in round 94 as the price of the cheapest licence passed $£ 2$ billion $(\$ 3$ billion), and four more withdrawals followed almost immediately. ${ }^{50}$ However the last three withdrawals took longer. The final bid took the cheapest licence price past $£ 4$ billion ( $\$ 6$ billion), and after 150 rounds of bidding the auction finished on 27 April, 2000 with a

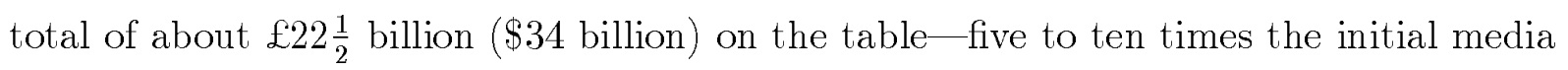
estimates. $^{51}$

The four incumbents won licences, with Vodafone paying about $£ 6$ billion ( $\$ 9$ billion) for licence B, compared with the $£ 4$ billion ( $\$ 6$ billion) or so paid by the other incumbents

\footnotetext{
${ }^{49}$ The investment bankers advising the government (N.M. Rothschild and Sons Ltd.) were paid a fee that depended on the number of bidders who participated in the auction. By attracting 13 bidders, Rothschilds earned $£ 4,770,000$, or over forty times the total expenditure on economic consultancy (see note 1).

${ }^{50}$ The rush of dropouts can be interpreted either as agreement among this group of bidders about the values, or as agency problems that meant that no management wished to be seen to be the first to quit. The former seems to be the case: it became known afterwards that several bidders had secured funding up to $£ 2$ billion.

${ }^{51}$ The British Treasury used the money towards paying off the National Debt.
} 
for each of licences C, D and E. The reserved licence $A$ was taken by the entrant TIW (largely owned by Hutchison Whampoa) for about $£ 4.4$ billion ( $\$ 6.6$ billion).

The final outcome cannot, of course, be proved to be efficient, but the evidence strongly suggests it was, in the sense of maximising the sum of the valuations of the bidders who were awarded licences, given the number and sizes of licences that were sold (see Section 3). See Börgers and Dustmann (2001) and Plott and Salmon (2001) for detailed analyses of the bidding. ${ }^{52}$

While the auction proceeded, our chief task was to advise on the size of the minimum percentage raise, which fell gradually from $5 \%$ to $1.5 \%$ largely in response to bidders' preferences. We also urged with only limited success that the auction be speeded up by running more rounds per day, lest some external event derailed the process by leading the bidders to adjust their valuations downwards. In fact, there was a major dip in share prices during the auction as the market corrected for over-optimistic investment in e-commerce companies, but this event seems to have had little impact on the bidders.

The arrangements for waivers and recess days (to allow consultation with financial backers) seemed to work out well, and the auction process was sufficiently well organized as to provoke compliments from several bidders, including those who did not win licences.

However, media criticism began immediately about the bidders being "forced" to pay too much for their licences (see Section 2). But Hutchison sold $35 \%$ of its holding in TIW to KPN and NTT DoCoMo, valuing the licence it won for $\mathcal{L} 4.4$ billion in late April at about $£ 6$ billion in early July. Moreover, after Orange had won and committed to pay for a licence, France Telecom paid $£ 6$ billion more for Orange in May than the price

\footnotetext{
${ }^{52}$ Bidders did not follow the simple bidding rule discussed in Section 5.2 of always making the minimum raise possible on the licence on which they bid (Börgers and Dustmann, 2001). However, the deviations were not substantial and some deviations from this rule are optimal for a bidder and so to be expected when the minimum allowable raises are not negligible. Börgers and Dustmann also argue BT's bidding seems erratic, although it might be largely explained by common-value components to valuations and by BT wishing to push up the price Vodafone paid for a large licence.

Furthermore, in the early stages of the contest, when it was clear that there was no realistic chance of the auction ending very quickly (even up to round 120, eight bidders still remained in the auction), some bids were probably slightly frivolous, or designed to attract media attention. For example, One2-One raised their bid by slightly more than the minimum required in round 76 to bid $£ 1,212,100,000$ ! (Additional 1's and 2's were ruled out, because all bids were required to be multiples of $£ 100,000$.)

While Börgers and Dustmann's analysis makes clear that the behaviour they document means that the auction ran the risk of a slightly inefficient conclusion, it also seems clear that the actual outcome was efficient or very close to efficient in the sense of Section 3. (It seems clear after the fact-and after the other European auctions - that the four incumbents had the highest valuations, so were appropriate winners in the sense of Section 3, and it is extremely implausible that any losing entrant quit the auction with a value for a licence that exceeded TIW's. Furthermore, the evidence both during and subsequent to the auction suggests Vodafone had a higher incremental value for a large licence than did any other incumbent, and therefore that the allocation of licences among winners was also correct.)
} 
Mannesmann had paid for it in the previous October, before the auction. Neither event suggests that the firms or the market shared the concerns expressed by the media in the months immediately following the auction. ${ }^{53}$

Of course, confidence in hi-tech industries in general has waned since that time. But the auction design deserves neither praise nor blame if the values placed on the $3 \mathrm{G}$ licences have now fallen because of a change in the capital market's view of 3G's prospects.

\subsection{Mistakes}

What could have been done better in organizing the British 3G auction? ${ }^{54}$ Neither of the problems we mention next actually caused any disruption, but they might have done if circumstances had been adverse.

We think the chief problem was the inadequacy of the deposits that the bidders were required to put down. These began at $£ 50$ million (about $\$ 75$ million), ratcheting up to $£ 100$ million when the bidding for any licence reached $£ 400$ million. This might not provide an adequate disincentive for a winner in the auction who changed his mind about wanting a licence after bidding several billions. ${ }^{55}$ Fortunately, the winners were uninterested in defaulting and all quickly paid their entire bids. We should have been stouter in our resistance to the imposition of an upper bound on our original proposal that deposits should ratchet up with the amounts bid.

With such small deposits, the slow pace at which the auction was run became more significant. The reserve prices were very low (see Section 4.4), and there was, in our view,

\footnotetext{
${ }^{53}$ Furthermore one winner claimed afterwards that it had predicted the final auction price to within $10 \%$ of the actual price, in advance of the auction. And when the prices in the U.K. auction had reached less than half their final levels, a new entrant in Germany announced a willingness to pay over $£ 5 \frac{1}{2}$ billion (18 billion DM) for a similar license in Germany.

More formal evidence is provided by Cable et al (2001) whose analysis of share price movements using event-study methodology suggests that, at the time of the auction, the market did not feel that the winners overpaid. Cable et al also "conclude there is no evidence that the outcome of the auction was anything but efficient".

${ }^{54}$ We restrict attention to issues within our terms of reference excluding, for example, grand issues like whether there should have been one single pan-European auction, or how the terms for any infrastructure sharing should have been determined.

${ }^{55}$ From a narrow economic perspective the deposits were clearly too small to ensure there were no defaults. From the perspective of a manager who might have to explain to others why he has given up $£ 100$ million for nothing, the deposit might suffice to persuade him to swallow any doubts he has about going through with the licence purchase.

Note that the winning bidders were required to pay at least half their bids almost immediately after winning their licences, and the repayment terms were such that every winner in fact chose to pay its full bid within days of receiving its licence.

The losers' deposits were completely refundable.
} 
an unnecessary maximum of $5 \%$ on the size of the minimum increment. The number of rounds per day was also much smaller than we would have liked and there were many recesses for holidays and weekends. ${ }^{56}$ We were very concerned that some external event might occur during the auction that would lead the bidders to lower their valuations below what they had already bid. What would have happened if a very negative discovery about the health implications of mobile phones had been made and reported during the auction? We were much less comfortable during the $7 \frac{1}{2}$ weeks of the auction than we pretended to be. There was in fact a substantial dip in technology share prices during the auction that looked as though it might create a confidence crisis, but this scare proved to be only a paper tiger at the time, although it looks more like a real tiger now.

\subsection{Telecom Auctions Elsewhere}

Subsequent telecom licence auctions seem to justify some of our decisions, and reinforced our view that the officials we had worked with had done an impressive job in managing the auction process.

\section{Facilitating Entry}

Our emphasis on the importance of entry was richly confirmed by the miserable failure of the very next European 3G auction: the Netherlands used an ascending design even though they were selling exactly as many licences as they had $2 \mathrm{G}$ incumbents-precisely the setting in which we had decided not to risk a pure ascending auction. As one of us predicted in advance, in the press and in Klemperer (May 2000c), their July auction was a disaster. ${ }^{57}$ Only one weak entrant showed up to compete with the $2 \mathrm{G}$ incumbents, and the auction raised just $\$ 2 \frac{1}{2}$ billion instead of the $\$ 8 \frac{1}{2}$ billion that the Dutch government had forecast based on the U.K. experience.

The Italian and Swiss 3G auction also had problems attracting entry, and we think that the Anglo-Dutch design - that the U.K. would have used if entry had been a concern there-would have worked better for these countries.

\section{Carefully Thinking Through and Testing the Rules}

A recent Turkish telecom auction illustrates the need to think through the implications of rules very carefully and often subject a design to careful experimental testing. The

\footnotetext{
${ }^{56} \mathrm{On}$ the other hand, some have argued that an auction of this size should be run slowly to give shareholders and directors adequate time to monitor and control their firms' bidding.

${ }^{57}$ See also Billions from Auctions: Wishful Thinking (Maasland, 9 June 2000).
} 
Turkish government auctioned two licences sequentially, but set the reserve price for the second licence equal to the price at which the first licence was sold. One company then bid much more for the first licence than the market thought it could be worth if the company had to compete with a rival holding the second licence. But the company had rightly figured that no rival would be willing to bid that high for the second licence, which therefore remained unsold, leaving the company without a rival operating the second licence!

Either careful thought or a few laboratory trials would have exposed this problem. ${ }^{58}$

\section{Market Structure}

The Turkish fiasco illustrates another point too: that if the choice of the number of licences is left to "the market", the choice is likely to favour the industry. The sale of just one licence in Turkey both increased industry profits and reduced social welfare relative to the sale of two. Other auction forms can yield different distortions, and it is hard to rule out distortions in any simple auction form that leaves the number of licences endogenous to the auction. Though the German 3G endogenous-number-of-licences auction worked well, this was probably due more to good luck than good design. The same design proved very vulnerable to collusion and yielded a very poor outcome when used in the Austrian 3G auction. See Klemperer (2002a, b).

\section{Other Issues}

The later European 3G auctions suffered from other problems too-in particular, firms' formation of joint-bidding agreements once they had seen how costly the competitive U.K. auction was. Ideally, auctioneers and/or anti-trust agencies should prohibit such agreements.

Furthermore, although on the whole it was a disadvantage to go to market later, the later countries could have used the information from the earlier auctions to set more realistic reserve prices. Their failure to do this, combined with their other errors, led to embarrassing results, especially for the Austrian and Swiss governments.

The failure of most of the $3 \mathrm{G}$ auctions after the U.K. auction is often attributed to a turn-round in market sentiment about the likely profitability of $3 \mathrm{G}$, and to the increase in firms' costs of capital to which this led. But the problem was severely exacerbated in most

\footnotetext{
${ }^{58}$ The Turkish government has now trumped this move by making arrangements for a new sale of the unsold licence, but who will believe that it will stand by its auction rules in the future?
} 
countries by their choice of auction designs that were inappropriate to their particular circumstances. One of us wrote shortly after the U.K. auction that other "European governments would be foolish not to copy the U.K. in auctioning the radiospectrum, but they would be equally foolish to blindly copy the U.K. design without attention to their local circumstances" (Klemperer, 2000c). We stand by that advice.

More detailed discussion of all nine 2000-2001 western European 3G auctions can be found in Klemperer (2002a, b).

\section{Conclusion}

We learnt a lot in advising on the telecom auction.

The auction confirmed our view that industrial-organization issues are more important than the informational issues on which the auction literature has mostly focused. In particular, the problems of attracting entrants and dealing with alliances and mergers are likely to remain major preoccupations of telecom-auction designers for the foreseeable future. Tackling such problems sensibly requires high-quality market research that keeps pace with developments in an industry that can change its clothes with bewildering rapidity. We also need more theoretical work on the industrial-organization implications of major auctions.

The really bad mistake in running an auction is just to take an auction design off the shelf, as shown by a comparison of the British and subsequent European 3G auctions. Auction design is a matter of "horses for courses", not one size fits all; each economic environment requires an auction design that is tailored to its special circumstances.

Starting the planning early was invaluable in giving us time to carefully think through and test our ideas. It was also important to start marketing the auction to potential entrants early; attracting bidders is not only about good auction design.

We learnt the need to widen our horizons to a whole range of legal and commercial issues. One cannot afford to defer to special experts in these fields, because they are frequently insensitive to the gaming opportunities that various measures may create for the bidders in a major auction. One must be ready to read the small print and to generate user-friendly examples of what might go wrong.

The value of computer simulations as an educational tool, and the persuasive power of laboratory experiments, was also brought home to us.

But perhaps the most important lesson of all is not to sell ourselves too cheap. Ideas 
that seem obvious to a trained economist are often quite new to layfolk. Our marginal product in preventing mistakes can therefore sometimes be surprisingly large.

\section{References}

Abbink, K., Irlenbusch, B., Pezanis-Christou, P., Rockenbach, B., Sadrieh, A., and Selten, R. (2001). 'An Experimental Test of Design Alternatives for the British 3G/UMTS Auction', Working Paper, University of Bonn.

Ballard, C. L., Shoven, J. B., and Whalley, J. (1985). 'General Equilibrium Computations of the Marginal Welfare Costs of Taxes in the United States', American Economic Review, vol. 75 , pp. $128-138$.

Börgers, T. and Dustmann, C. (2001). 'Strange Bids: Bidding Behaviour in the United Kingdom's Third Generation Spectrum Auction', Working Paper, University College, London.

Brusco, S. and Lopomo, G. (1999). 'Collusion via Signalling in Open Ascending Auctions with Multiple Objects and Complementarities', Working Paper, Stern School of Business, New York University.

Bulow, J. and Klemperer, P. (1996). 'Auctions vs. Negotiations', American Economic Review, vol. 86, pp. 180-194.

Bulow, J. and Klemperer, P. (1998). 'The Tobacco Deal', Brookings Papers on Economic Activity: Microeconomics, pp. 323-94.

Bulow, J. and Klemperer, P. (2002). 'Prices and The Winner's Curse', Rand Journal of Economics, vol. 33, forthcoming. 
Bulow, J., Huang, M., and Klemperer, P. (1999). 'Toeholds and Takeovers", Journal of Political Economy, vol. 107, pp. 427-454.

Cable, J., Henley, A., and Holland, K. (2001). 'Pot of Gold or Winner's Curse? An event study of the auctions of 3G mobile telephone licences in the UK', Working Paper, School of Management and Business, University of Wales, Aberystwyth.

Cai, H-B. (1997). 'Delay in Multilateral Bargaining under Complete Information', Working Paper, Los Angeles: University of California.

Coase, R. H. (1959). 'The Federal Communications Commission', Journal of Law and Economics, vol. 2, pp. 1-40.

Cramton, P., Gibbons, R. and Klemperer, P. (1987). 'Dissolving a Partnership Efficiently', Econometrica, vol. 55, pp. 615-32.

Cramton, P. and Schwartz, J.A. (1999). 'Collusive Bidding in the FCC Spectrum Auctions', Working paper, University of Maryland.

Cramton, P. and Schwartz, J.A. (2000). 'Collusive Bidding: Lessons from the FCC Spectrum Auctions', Journal of Regulatory Economics, 17, forthcoming.

Engelbrecht-Wiggans, R. and Kahn, C.M. (1998). 'Low Revenue Equilibria in Simultaneous Auctions', Working paper, University of Illinois.

Feldstein, M. (1999). 'Tax Avoidance and the Deadweight Loss of the Income Tax', The Review of Economics and Statistics, November.

Gibbon, E. (1776). 'History of the Decline and Fall of the Roman Empire', London: Strahan and Cadell.

Gilbert, R. and Klemperer, P. (2000). 'An Equilibrium Theory of Rationing', Rand Journal of Economics, vol. 31, pp. 1-21.

Hansard, (18 May 1998), written answer to Parliamentary Question.

Jehiel, P. and Moldovanu, B. (1996). 'Strategic Nonparticipation', Rand Journal of Economics, vol. 27 , pp. 84-98. 
Jehiel, P., Moldovanu, B. and Stacchetti, E. (1996). 'How (Not) to Sell Nuclear Weapons', American Economic Review, vol. 86, pp. 814-29.

Jehiel, P. and Moldovanu, B. (2001). 'The European UMTS/IMT-2000 License Auctions', Working Paper, University College London and University of Mannheim.

Klemperer, P. (1998). 'Auctions with Almost Common Values', European Economic Review, vol. 42, pp. 757-69.

Klemperer, P. (1999). 'Auction Theory: A Guide to the Literature', Journal of Economic Surveys, vol. 13: 3, pp. 227-286. (Also reprinted in The Current State of Economic Science (1999) (ed. S. Dahiya) vol. 2, pp. 711-766.)

Klemperer, P. (2000a). 'Why Every Economist Should Learn Some Auction Theory', forthcoming in Advances in Economics and Econometrics: Invited Lectures to Eighth World Congress of the Econometric Society (2000), (eds. M. Dewatripont, L. Hansen, and S. Turnovksy) Cambridge, U.K.: Cambridge University Press, and available at www.paulklemperer.org.

Klemperer, P. (2000b). The Economic Theory of Auctions (ed.), Cheltenham, U.K.: Edward Elgar.

Klemperer, P. (2000c). 'What Really Matters in Auction Design', May 2000 version, available at www.paulklemperer.org.

Klemperer, P. (2000d). 'Spectrum on the Block', Wall Street Journal, Oct 5. p.8 and available at www.paulklemperer.org.

Klemperer, P. (2002a). 'How (Not) to Run Auctions: The European 3G Telecom Auctions', European Economic Review, vol. 46, forthcoming.

Klemperer, P. (2002b). 'What Really Matters In Auction Design', Journal of Economic Perspectives, vol. 16, forthcoming.

Klemperer, P. and Pagnozzi, M. (2002). 'Advantaged Bidders and Spectrum Prices: An Empirical Analysis, forthcoming at www.paulklemperer.org.

McAfee, R. P. and McMillan, J. (1996). 'Analyzing the Airwaves Auction', Journal of Economic Perspectives, vol. 10, pp. 159-75. 
Maasland, E. (2000). 'Veilingmiljarden Zijn een Fictie (Billions from Auctions: Wishful Thinking'), ESB June 9: pp. 479 and translation available at www.paulklemperer.org.

Milgrom, P.R. (2000). 'Putting Auction Theory to Work: The Simultaneous Ascending' Auction', Journal of Political Economy, vol. 108, pp. 245-272.

Milgrom, P.R. Forthcoming. 'Auction Theory for Privatization', Cambridge: Cambridge University Press.

Milgrom, P. R. and Weber, R., (2000). 'A Theory of Auctions and Competitive Bidding: II', in The Economic Theory of Auctions, (ed. P. Klemperer), Cheltenham, U.K.: Edward Elgar.

Myerson, R.B. and Satterthwaite, M.A. (1983). 'Efficient Mechanisms for Bilateral Trade', Journal of Economic Theory, vol. 29, pp. 265-81.

National Audit Office (2001). The Auction of Radio Spectrum for the Third Generation of Mobile Telephones, London : The Stationery Office, and available at www.nao.gov.uk.

Pagnozzi, M. (2002). 'Sorry Winners', Working Paper, Oxford University.

Plott, C., and Salmon, T. (2001). 'The Simultaneous, Ascending Auction: Dynamics of Price Adjustment in Experiments and in the Field', Mimeo, California Institute of Technology and Florida State University.

Vickrey, W. (1976). 'Auctions Markets and Optimum Allocations', in Bidding and Auctioning for Procurement and Allocation. Studies in Game Theory and Mathematical Economics. Yakov Amihud, ed. New York: New York University Press. pp. 13-20.

Wruck, K.H. (1994). 'Financial Policy, Internal Control, and Performance: Sealed Air Corporation's Leveraged Special Dividend', Journal of Financial Economics, vol. 36, pp. $157-192$.

Amended as at 17.30 on Friday 18 January 2002 